\title{
STRESS, SELF-EFFICACY AND WELL-BEING OF THE UNIVERSITY STUDENTS
}

\section{Hana Chýlová, Ludmila Natovová}

\section{Abstract}

This research is a follow-up to a previous study on the preferred stress coping strategies of students that ascertained rather unsettling result of surprisingly high number of negative strategies. This paper aims to investigate the levels of perceived self-efficacy and satisfaction with life (subjective well-being) in connection to stress coping strategies in a sample of university students.

The data were collected on a sample of 387 respondents with the use of three standardized questionnaires: General Self-Efficacy Scale, The Satisfaction With Life Scale and The Stress Coping Style Questionnaire. The significance of the difference between the means of our sample and other relevant samples was tested via t-test. Correlation coefficient was computed for self-efficacy, well-being, positive coping strategies and negative coping strategies.

The key findings of the study are that students in our sample perceive their general self-efficacy to be significantly heightened, while they are less satisfied with their lives than the normal population. Furthermore, we found significant correlations between self-efficacy and stress coping strategies, which induce, that the concept of selfefficacy is a strong and useful concept that deserves to be included into psychological seminars and contact lessons in education of our students.
Czech University of Life Sciences Prague chylova@pef.czu.cz

\section{ARTICLE INFO}

Article type

Full research paper

doi: 10.7160/eriesj.2013.060306

Article history

Received: July 31, 2013

Received in revised form: September 5, 2012

Accepted: September 6, 2013

Available on-line: September 30, 2013

\section{Key Words}

Coping, self-efficacy, stress, university students, well-being 


\section{Introduction}

Stress related to the numerous demands placed on university students during their studies has often led to high perceived distress, discomfort and overall dissatisfaction. These phenomena, with a particular focus on stress coping strategies and their connection with the health behaviour issues of the university student population, were discussed in Chýlová, Natovová and Kolman (2012), Natovová and Chýlová (2012), Chamoutová and Chýlová (2008). The outcomes of these sombre setting are usually also connected with poor academic performance (Cicognani, 2011, Kausar, 2010, Nickerson, Diener and Schwarz, 2011). The positive side, the belief in one's resources and capacity to cope with stressful events, the use of positive stress coping strategies and increase in overall satisfaction with life (well-being) should be in a focus of educators and researchers as well.

Even though this paper is a follow up of the previous research study of the composite authors, it seems to be important to clarify the basic terminology, which is going to be used throughout the following text. Carver (2011, p. 222) defines coping as "efforts to deal with a threatening or harmful situation, either to remove the threat or to diminish the ways in which it can have an adverse impact on the person." Well-known definition of coping from Lazarus and Folkman (1984) describes coping as cognitive and behavioural responses that people use in order to manage their stress. Kebza (2005) mentions the commonly used classification of coping strategies - problem-focused coping, emotion-focused coping and avoidance-oriented coping.

From our previous research work, we have learnt that some of the coping strategies used by our students significantly differ from strategies used by general Czech population (Chýlová and Natovová, 2012). There can be found certain gender differences in coping, as well as differences between part-time and full-time students (Natovová and Chýlová, 2012). In our settings, this kind of studies tried to take into account the age of respondents with respect to stress coping strategies. Lukavský, Šolcová and Preiss (2011) focused their research on a proactive stress coping at a group of seniors, Baumgartner and Karaffová (2012) studied coping at young adults and adolescents in a connection with the concept of so called "emerging adulthood".

The authors of this study are reporting the outcomes of research on the general self-efficacy, and perceived well-being of the students' population, which is a follow-up to a previous study on the preferred stress coping strategies of students, that ascertained rather unsettling result of surprisingly high number of negative strategies and a low number of positive constructive strategies used (Chýlová, Natovová and Kolman, 2012).

Stress coping models (Lazarus and Folkman, 1984) emphasize the role of individual's resources in influencing his or her appraisal of stressful events and coping strategies, self-efficacy being an important individual resource. Major health behaviour theoretical and research constructs include the concept of selfefficacy as a proximal and direct predictor of intention and behaviour (Schwarzer and Luszczynska, 2008).

Albert Bandura (1997, Bandura and Locke, 2003), as the creator of the concept of self-efficacy, defines perceived selfefficacy as the belief about whether one can produce certain actions, whether one is able to succeed in a particular situation. Bandura described these beliefs as determinants of how people think, feel and, moreover, he claims that it is a uniformly good predictor of the same behaviours. That might be powerful reason why self-efficacy has become one of the most studied 
topics among psychologists and educators - it can have an impact on everything from psychological states to motivation and behaviour.

General self-efficacy is the belief in one's competence to cope with a broad range of stressful or challenging demands, whereas specific self-efficacy is constrained to a particular task at hand (Luszczynska, Scholz and Schwarzer, 2005).

"A fundamental goal of education is to equip students with selfregulatory capabilities that enable them to educate themselves" (Bandura, 1997, p. 174). A strong sense of efficacy fosters a high level of motivation, academic accomplishments and development of intrinsic interest in academic subject matter (Bandura, 1997). In other words - the stronger the students' belief in self-efficacy the stronger is their cognitive growth. As stated by Bandura and Locke (2003), perceived self-efficacy is apprehended as an important contributor to academic accomplishments, achievement enhancement and many aspects of well-being. The relations between general self-efficacy, stress appraisal, well-being and achievement in a broad range of stressful or challenging encounters were explored by Luszczynska, Gutierrez-Dona and Schwarzer (2005) across several countries. Social cognitive theory (Bandura and Locke, 2003) expects that self-efficacy positively influences the performance in any kind of task. However, Neal (2003) suggests that the relation does not have to be necessarily straightforward; on account of his preliminary studies on ambiguous performance feedback, where negative effect of self-efficacy on within-person performance level was found. According to Slezáčková (2012), the outcomes of a number of studies highlight the important protective role of self-efficacy against stress, as well as its role regarding a close connection to the quality of life, effective coping with stress, and other desirable variables. Self-efficacy also shows its importance in stress-coping training. Griffin and Clark (2011) mention the diminishing function of high selfefficacy on the negative effects of workload. Schwarzer (1997) recommends using the general self-efficacy scale in screening people at risk for coping deficiencies.

As it was already mentioned, Bandura (1997, Bandura and Locke, 2003) sees self-efficacy as a causal contributor to human well-being and accomplishments. Also Kebza (2005) considers self-efficacy to be one of the main components of well-being. However, well-being is frequently viewed as an important intervening variable in itself. For example, the research study of Cicognani (2011), who also reported an increase in the number of coping strategies used by adolescents, specifically an increase in tension reducing strategies (alcohol abuse, drugs, etc.), was therefore concentrated on finding the relationship between coping strategies and supportive factors such as self-efficacy or well-being among adolescents.

Well-being can be considered as a global term designating the subjective mental and health ease. By accentuating the subjective experience, the term might be understood as mainly psychological, nevertheless, it is connected with other sciences as well, namely medicine, philosophy, pedagogy, economics, political sciences etc. (Paulík, 2010). Well-being is frequently assessed as a part of the concept of so called "quality of life", which is usually expressed as a combination of mutually interconnected factors: well-being, subjective assessment of one's health condition and life satisfaction. Even though some authors consider well-being to be a key factor and recommend to standardly monitor it in various contexts (Kebza 2005; Hodačová et al., 2011).

The last three decades witnessed a dramatic increase in research on the construct of subjective well-being (Pavot and Diener, 
2008) Current approaches to subjective evaluation of quality of life are heterogeneous and thus researchers try to provide a unified starting point-complex model or the attempt to organize existing measurements (Džuka, 2012). Subjective quality of life can be identified through subjective indicators of life quality and ease - Diener and Suh (1997) considered the concept of well-being to be the emerging construct. Martin Seligman (2011) in his newest reconsideration of a happiness theory states that well-being has several contributing elements - positive emotions, engagement, meaning, positive relationships, and accomplishment.

Diener and Diener (1996) refer to subjective well-being as to a person's evaluation of his or her life. In their article "Most People Are Happy" (1996), they hypothesise that people might be motivated to attain positive states and to avoid or reduce unpleasant states and therefore may be likely to use positive coping strategies and, as a result, be mainly happy. Diener et al. (1985) claim that it is possible to isolate various components of subjective well-being: affective, emotional aspects (positive and negative affects) and cognitive, judgemental aspects - life satisfaction. Judgment of life satisfaction is dependent upon a subjective comparison of one's circumstances with what one considers to be the appropriate standard. In his recent studies Diener (Nickerson, Diener and Schwarz, 2011 or Diener et al., 2002) paid attention to the relation between positive affect and college success, respectively job outcomes.

The paper aims to investigate the levels of perceived selfefficacy and satisfaction with life (subjective well-being) in connection to stress coping strategies in a sample of university students from Czech University of Life Sciences in Prague. As mentioned previously, a higher level of perceived self-efficacy leads to a higher use of constructive ways of coping with stressful situations, which is the main concern of the authors. The other assumed outcome of a higher level of self-efficacy, overall well-being and satisfaction with life, is also explored.

The present study is of the descriptive (exploratory) research design, aiming at an exploration of the subject matter using three standardized questionnaires: Stress Coping Styles Questionnaire - SVF 78 (Janke and Erdmann, 2003), General Self-efficacy Scale - GSES (Schwarzer and Jerusalem, 1995) and Satisfaction With Life Scale - SWLS (Diener et al. 1985). The results for our participants will be statistically compared to the results for the standardized groups in order to estimate the level of the explored characteristics. GSES questionnaire was standardized on a sample of Germans (in its country of origin), currently are available also data from students of economy and entrepreneurs from Czech Republic, which will represent other relevant group for comparison. For a group of respondents, who completed questionnaires on stress coping styles as well as on general self-efficacy, a statistical correlation of the results will be run in order to ascertain the plausibility of the hypothesis of their mutual relationship.

\section{Materials and Methods}

\section{Participants}

The data were collected during the academic years 2011/2012 and 2012/2013 from a sample of 387 students of the Czech University of Life Sciences in Prague. Participants came from various programmes of study (including both full-time and part-time students), different years of study (ranging from the 1st year of bachelor's studies to the 1st year of master's 
studies), and two different faculties - the Faculty of Economics and Management and the Faculty of Agrobiology, Food and Industry.

\begin{tabular}{|l|c|c|c|c|c|c|}
\hline $\begin{array}{l}\text { Groups of } \\
\text { respondents }\end{array}$ & $\begin{array}{c}\mathrm{N} \\
(\mathrm{N} \text { valid })\end{array}$ & $\begin{array}{c}\text { Women } \\
(\mathrm{N})\end{array}$ & $\begin{array}{c}\text { Women } \\
(\%)\end{array}$ & $\begin{array}{c}\text { Men } \\
(\mathrm{N})\end{array}$ & $\begin{array}{c}\text { Men } \\
(\%)\end{array}$ & $\begin{array}{c}\text { Mean } \\
\text { age }\end{array}$ \\
\hline GSES group & $280(276)$ & 186 & 66,43 & 94 & 33,57 & 24,83 \\
\hline SWLS group & $238(238)$ & 161 & 67,65 & 77 & 32,35 & 21,87 \\
\hline SWLS + GSES group & $80(77)$ & 52 & 65 & 28 & 35 & 32,14 \\
\hline $\begin{array}{l}\text { All participating } \\
\text { respondents }\end{array}$ & 438 & 296 & 67,5 & 142 & 32,49 & 21,86 \\
\hline
\end{tabular}

Table 1: Descriptive statistics of the group of respondents.

In our previous research work, which was already mentioned (Chýlová and Natovová, 2012), we described the use of coping strategies at students of Czech University of Life Sciences. We compared our sample to standardized Czech population sample and found out, that our students significantly differ in the use of positive and also in the use of negative coping strategies, however, not in a positive way. Students use significantly less the most constructive and, in long-term perspective, most approved group of strategies (third group of positive strategies, which includes control of reactions, control of emotions and positive self-instructions). This research work continued with comparing the groups of part-time and full-time students and also with comparing age differentiated groups (age $\leq 23$, age $\geq 24$ ). We found similar differences in the use of coping strategies in different age groups and also in different study-mode groups, especially regarding the use of the positive triad: situation control, reaction control and positive self-instruction (Natovová and Chýlová, 2013).

\section{Method}

In order to attain the data necessary for the intended analysis, three paper-and-pencil standardized psychological questionnaires were distributed to the participants (General Self-Efficacy Scale, The Satisfaction With Life Scale and The Stress Coping Style Questionnaire).

The General Self-Efficacy Scale (GSES) was created by Schwarzer and Jerusalem (1995) to predict coping with daily hassles as well as adaptation after experiencing various kinds of stressful life events. The scale includes 10 items measuring global feelings of self-efficacy. Responses are given on a 4-point scale ( 0 - not at all true; 3 - completely true). Responses to all 10 items are summed up to yield the final composite score. Typical items are "Thanks to my resourcefulness, I know how to handle unforeseen situations," and "When I am confronted with a problem, I can usually find several solutions." Cronbach's alphas range from 0,76 to 0,90 . The mean score on GSES is 28,63 , with a standard deviation of 6,18 (Scholz et al, 2002). There is consistent evidence for associations between perceived selfefficacy and the variables under study confirming the validity of the psychometric scale. General self-efficacy appears to be a universal construct that yields meaningful relations with other psychological constructs (Luszczynska, Scholz and Schwarzer, 2005). A Czech adaptation of the scale, created by Krivohlavy (Krivohlavy, Schwarzer and Jerusalem, 1993), was used for the purpose of this study. 
The Satisfaction With Life Scale (SWLS) is a scale designed by Diener et al. (1985) to measure global life satisfaction. Of the various components of subjective well-being, the SWLS is narrowly focused on assessing global life satisfaction and does not involve any related constructs. The SWLS consists of 5-item scales, where participants indicate how much they agree or disagree with each of the items using a 7-point scale that ranges from 7 (strongly agree) to 1 (strongly disagree). Typical items are "The conditions of my life are excellent", "In most ways my life is close to my ideal" (Diener et al., 1985). Pavot and Diener (2008) refer to the favourable psychometric properties of SWLS, including its high internal consistency and high test-retest reliability $(0,82)$, Cronbach's alpha 0,87. The mean score on the SWLS is 23,5 , with a standard deviation of 6,43 (Pavot and Diener, 1993).

The Stress Coping Style Questionnaire (SVF 78) questionnaire was created by Janke and Erdmann (2003) and was introduced in detail in our previous studies (Natovová et al., 2012, Chýlová and Natovová, 2012). In summary, it is a questionnaire where subjects decide for each item how likely the reaction presented corresponds to his or her way of reacting, when he/she is "... disturbed, irritated or upset by something or someone..." (Janke and Erdmann, 2003). The SVF 78 has 13 subscales and contains 78 items. Positive coping strategies are measured on scales $1-7$ and divided into three subgroups of positive strategies, while scales $10-13$ measure negative coping strategies. In this research, we also focus on the analysis of self-efficacy and stress vulnerability variables in relation to the three groups of positive strategies mentioned above. Positive Strategies 1 include the subscales minimization and denial of guilt, Positive Strategies 2 contain the subscales distraction and substitute gratification, and the group of positive coping strategies is completed by the subscales situation control, reaction control and positive self-instruction (Positive Strategies 3). SVF 78 is a reliable and valid psychodiagnostic tool adapted also for the use in Czechspeaking environment (Janke and Erdmann, 2003).

\section{Statistical analysis}

As for a statistical analysis of the data, besides descriptive statistics of the sample (Mean, Standard Deviation and Standard Error Mean), we will test the significance of the difference between the means of our samples and the means of other relevant samples (students of the University of Economics in Prague - VSE students, Czech entrepreneurs, and a standardized sample of the GSES group; a standardized sample of the SWLS group) via one sample t-test.o answer the other research question, whether a correlation exists between the variables: self-efficacy (GSES), well-being (SWLS), positive coping strategies (SVF - Positive strategies), negative coping strategies (SVF - Negative strategies), as well as between the groups of positive coping strategies (Positive strategies 1, Positive strategies 2, Positive strategies 3), Spearman correlation coefficient will be computed. The data processing will be done with the use of the SPSS 19 programme (Norušis, 2011).

\section{Results}

The results of the descriptive statistical analysis show that the mean value of Self-efficacy (GSES) in our sample is 28,45. The mean value of Well-being (SWLS) is 22,7. Other details on descriptive characteristics of these two scales (within each respective group of 238 and 227 respondents, whose questionnaires were valid; 4 questionnaires on GSES were incorrectly filled in and therefore not used for further analysis) are displayed in Table 2, below: 


\begin{tabular}{|c|c|c|c|c|}
\cline { 2 - 5 } \multicolumn{1}{c|}{} & $\mathrm{N}$ (valid) & Mean & Std. Deviation & $\begin{array}{c}\text { Std. Error } \\
\text { Mean }\end{array}$ \\
\hline $\begin{array}{c}\text { Satisfaction with Life } \\
\text { Scale }\end{array}$ & 238 & 22,70 & 6,04 & 0,39 \\
\hline $\begin{array}{c}\text { General Self-efficacy } \\
\text { Scale }\end{array}$ & 276 & 29,66 & 3,80 & 0,23 \\
\hline
\end{tabular}

Table 2: Results - descriptive statistics values of the Satisfaction with Life Scale (SWLS) and General Self-efficacy Scale (GSES)

$$
\text { groups }
$$

The General Self-efficacy Scale (GSES) results were compared to the results of students of University of Economics in Prague on the same scale (Lukeš et al., 2004) in order to ascertain the possible concordance or disparity of the self-perception of the two groups of students, that could be considered comparable (and often are compared in other opportunities). The mean value of perceived general self-efficacy of our students emerged to be significantly higher. In comparison of our participants to the group of entrepreneurs from the Czech Republic, we have found a significant negative difference between the means. Of the same sense and significance is also the difference between the mean of our students and the mean of the general German population. As for the values of Well-being, the results of our sample were significantly lower than those of the compared population. The detailed results are shown in Table 3.

\begin{tabular}{|c|c|c|c|c|c|c|}
\hline & \multirow[t]{2}{*}{$\mathrm{t}$} & \multirow[t]{2}{*}{ df } & \multirow{2}{*}{$\begin{array}{c}\text { Sig. } \\
\text { (2-tailed) }\end{array}$} & \multirow{2}{*}{$\begin{array}{c}\text { Mean } \\
\text { Difference }\end{array}$} & \multicolumn{2}{|c|}{$\begin{array}{l}\text { 95\% Confidence Interval } \\
\text { of the Difference }\end{array}$} \\
\hline & & & & & Lower & Upper \\
\hline \multirow{6}{*}{ 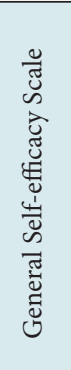 } & \multicolumn{6}{|c|}{ Test Value (VSE students) = 27, 36} \\
\hline & 10,05 & 275 & $0,00^{* *}$ & 2,30 & 1,85 & 2,75 \\
\hline & \multicolumn{6}{|c|}{ Test Value (entrepreneurs) $=31,02$} \\
\hline & $-5,95$ & 275 & $0,00^{* *}$ & $-1,36$ & $-1,81$ & $-0,91$ \\
\hline & \multicolumn{6}{|c|}{ Test Value $($ Germans $)=29,28$} \\
\hline & 1,66 & 275 & 0,10 & 0,38 & $-0,07$ & 0,83 \\
\hline$\equiv$ & \multicolumn{6}{|c|}{ Test Value $=23, .5$} \\
\hline 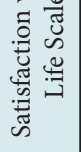 & $-2,04$ & 237 & $0,04^{*}$ & $-0,80$ & $-1,57$ & $-0,03$ \\
\hline
\end{tabular}

Table 3: Results - one sample t-tests of the Satisfaction with Life Scale (SWLS) and General Self-efficacy Scale (GSES) groups

Another key concern of our research was whether there exist the correlations between self-efficacy, well-being and groups of coping strategies. We used non-parametric Spearman correlation coefficient due to his robustness, our smaller sample size and ordinal character of the data. The values of correlation coefficients are shown at Table 4 , bellow. 


\begin{tabular}{|c|c|c|c|c|c|c|c|c|}
\hline & & 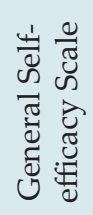 & 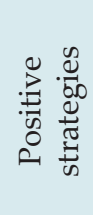 & 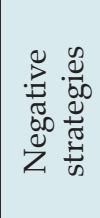 & 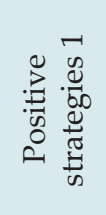 & 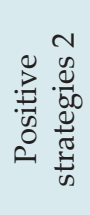 & 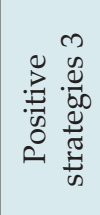 & 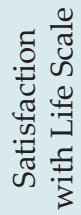 \\
\hline \multirow{3}{*}{ 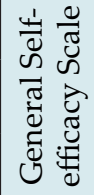 } & $\varrho$ & 1 & 0,56 & $-0,71$ & 0,48 & 0,03 & 0,53 & 0,17 \\
\hline & Sig. & - & $0,00^{* *}$ & $0,00^{* *}$ & $0,00^{* *}$ & 0,84 & $0,00^{* *}$ & 0,14 \\
\hline & $\mathrm{N}$ & 50 & 48 & 48 & 48 & 48 & 48 & 77 \\
\hline
\end{tabular}

${ }^{*} \alpha \leq 0.05 ;{ }^{* *} \alpha \leq 0.01 ; \mathrm{Q}=$ value of Spearman's correlation coefficient; Sig. is 2-tailed

Table 4: Values of Spearman's correlation coefficient for Satisfaction with Life Scale (SWLS), General Self-efficacy Scale (GSES) and Coping strategies

Table 4 clearly displays that self-efficacy significantly positively correlates with positive coping strategies in general $(\varrho=0,56)$, as well as with Positive Strategies $1(\varrho=0,48)$ and $3(\varrho=0,53)$. By contrast, in case of self-efficacy we have found statistically significant negative correlation with negative coping strategies $(\mathrm{Q}=-0,71)$. As Table 4 shows, we found no statistically significant correlation between self-efficacy and well-being (GSES and SWLS). This finding is not in line with theoretical findings above and needs further investigation. However, we can assume that people who have confidence in their ability to manage everyday problems and concerns in an effective and efficient way are also more likely to use positive coping strategies (including the last three most effective coping strategies labelled as Positive Strategies 3). At the same time, higher perceived self-efficacy may predict lower use of negative coping strategies. Bandura
(1997) generally presumes that people who have confidence in their ability to efficiently achieve their goals are also healthier, more successful and more effective. These people are also likely to experience a lower level of stress, similarly to the conclusions of Lazarus (1999, p. 102) "...when coping is ineffective, the level of stress is high; however, when coping is effective, the level of stress is apt to be low".

\section{Discussion}

The above-described results bring several pieces of knowledge about a sample of students from CULS that are not exactly in accord with the expectations formed on the basis of literature overview. Firstly the GSES values seem to indicate the fact that CULS students perceive their general self-efficacy to be higher than it might have been expected according to the findings made on a similar population of students of University of Economics in Prague (Lukeš et al., 2004). At the same time, CULS students are less satisfied with their life, judging their overall well-being to be lower than could be expected among a similar population, according to the results of Diener et al. (1985). It is therefore apparent that our findings are also not in concordance with Diener and Diener (1996), who concluded their study on satisfaction with life with the affirmation that naturally occurring processes give most people the ability to remain happy, that people are generally satisfied with their life - their work, marriage, leisure.

The authors of this research study primarily aimed at broadening of the area of stress studied on university students towards other related intervening variables, namely self-efficacy and well-being. Even though we are well aware that other variables might be considered in the future research as well - for example the fatigue and the burn-out syndrome. Burn-out syndrome 
is usually connected with negative emotions in relation to a profession, with demotivation, the loss of interest, however, some newer studies show also its interconnectedness with physiological markers (the stress hormones level) and thus with the level of cardiovascular and cerebrovascular diseases (Kebza, Šolcová, 2010). Similarly, Tanaka (2009) studied coping strategies adopted by university students in relationship to fatigue, and he found that fatigue and perceived level of stress and coping styles are closely correlated.

Should we ask about the reason for studying stress, coping, selfefficacy and well-being at university students, Tanaka (2009, p. 91) provides some answers "however, further efforts to develop educational training programmes that reduce stress and help guide individuals to develop efficient stress coping styles would contribute to a lower incidence of severe fatigue, a higher rate of recovery from severe fatigue, and even more favourable academic outcomes among (medical) students".

Refocusing our attention to the positive side of the issue, to the academic success, we note that there exist many studies of the relation between subjective well-being and life satisfaction and various indicators of college success (Nickerson, Diener and Schwarz, 2011). Frisch et al. (2005) conducted a longitudinal study on a quality of life of students and commented upon the results, that they extend the predictive validity of life satisfaction to a new domain of academic retention. Neal and Yeo (2003) previously contributed to the debate regarding the direction of the relationship between self-efficacy and performance. Presently Yeo and Neal (2013) represent new critical way of reconsideration of Bandura's original theory; in their brand new article they explain the importance of designing and analysing studies involving self-efficacy at the within-person level of analysis and in this sense they explain the contradictory co- existence of positive and negative dynamic self-efficacy effects across the between- and within-person levels of analysis, which might be of consideration for a future study.

Regardless the statistical significance of the number of the outcomes, we must be aware of the limitations of this study before trying to broaden its implications. First of them is a limited sample size. Our results describe students from Czech University of Life Sciences, not the entire Czech student population, and this fact needs to be taken into account, as this population seems to display certain unusual characteristics.

\section{Conclusion}

The most important point of the study is, as the results of statistical analysis show, that students in our sample differ in a number of ways from standardized samples and from a similar student population. CULS students have a significantly higher meaning of their general self-efficacy than other similar student population, while being less satisfied with their lives than the comparable student population. We found significant correlations between self-efficacy and stress coping strategies, which induce, that the concept of self-efficacy is a useful idea that deserves to be included into psychological seminars and contact lessons in education of our students.

Do the findings mentioned above imply that our students are generally dissatisfied while having heightened perception of their own capacities?

To answer any questions concerning differences in the general self-efficacy level and the nature of the dissatisfaction of our students would require further investigation. We found no correlation between self-efficacy and well-being. The proposed way of analysing self-efficacy on within-person level of analysis 
might be taken into account. The means of intervention should be set accordingly, as an understanding of the underlying mechanism of these processes can aid in their designing.

It is a task for teachers and educators to support the enhancement of positive and constructive ways of dealing with major as well as minor life events among students. The desired outcome of interventions is to support positive relations between general self-efficacy and supposed aspects connected with stress-coping strategies, and the use of their relations for the prevention of negative stress impacts and the further boost of the positive personal growth of students, as well as their overall well-being, satisfaction, and academic achievement.

Furthermore, we have identified relations between the level of perceived self-efficacy and most groups of coping strategies (positive, negative, as well as the first and third subgroups of positive coping strategies as distinguished by Janke and Erdmann, 2003). Self-efficacy therefore appears to be a meaningful concept that can be well used in education and counselling related to coping with stress. Our future research work in this area should be outlined here. We are planning to focus on various spheres of work and private life and the perception of such specific self-efficacy (e.g. self-efficacy in relation to study, self-efficacy in relation to sports activities, self-efficacy in partnership, etc., as mentioned by Bandura, 1997, for example). For the purpose of education and psychological counselling at CULS, possibilities of training activities aimed at enhancing perceived self-efficacy in students of the Faculty of Economics and Management of the Czech University of Life Sciences should also be considered.

Finally, we would like to answer the question whether it is important at all to think about the issues of coping with stress, self-efficacy and behaviours that can lead to higher vulnerability to stress in the academic environment. An answer to this question has been clearly formulated by Kausar (2010, p. 31) who notes that findings about relationship between academic workload, perceived stress and coping "have important implications for students in higher (in our case university) education and highlight the importance of counselling in the higher education institutions (universities) which in turn may help improve their academic performance."

We agree with the above noted quotation and although we are aware of some shortcomings, particularly in terms of the research sample size and selection, we believe that our results add to the growing body of evidence suggesting that the influence of self-efficacy and stress coping strategies on well-being and life satisfaction of students is more than just a coincidence and can be inspiring and beneficial both for educational and counselling work with students.

\section{References}

Bandura, A. (1995) Self-Efficacy in Changing Societies, Cambridge: Cambridge University Press.

Bandura, A. (1997) Self-Efficacy. The Exercise of Control, New York: W. H. Freeman and Company.

Bandura, A. and Locke, E. A. (2003) „Negative self-efficacy and goal effects revisited', Journal of Applied Psychology, vol. 88, no.1, pp. 87-99.

Baumgartner, F. and Karaffová, E. (2012) „Strategie zvládání ve vztahu $\mathrm{k}$ aspektům vynořující se dospělosti,,, Psychologie pro praxi, vol. 47, no. 1-2, pp. 11-25.

Carver, C. S. et al. (1989) "Assessing coping strategies: A theoretically based approach,,., Journal of Personality and Social Psychology, Vol. 56, No. 2, pp. 267-283. 
Chamoutová, K. and Chýlová, H. (2008) „Coping with stress at CULS students - A Comparison study ", Proceedings of the 5th International Conference on Efficiency and Responsibility in Education (ERIE 2008), Prague, pp. 88-91.

Chýlová, H., Natovová, L. and Kolman, L. (2012) „Preferred Stress Coping Strategies - A Case Study on CULS Students,,, Proceedings of the 9th International Conference on Efficiency and Responsibility in Education (ERIE 2012), Prague, pp. 175-183.

Chýlová, H. and Natovová, L. (2012) „Stress Coping Strategies at University Students - Part I: Gender Differences', Journal on Efficiency and Responsibility in Education and Science, vol. 5, no. 3, pp. 135-147, ISSN 1803-1617, [on-line], Available: www. eriesjournal.com/_papers/article_172.pdf [2012-09-30]. doi: 10.7160/eriesj.2012.050303.

Cicognani, E. (2011) „Coping Strategies With Minor Stressors in Adolescence: Relationships With Social Support, SelfEfficacy, and Psychological Well-Being,", Journal of Applied Social Psychology, vol. 41, no. 3, pp. 559-578.

Diener, E., Nickerson, C., Lucas, R., E. and Sandvik, E. (2002) „Dispositional affect and job outcomes,", Social Indicators Research, vol. 59, no. 3, pp. 229-259.

Diener, E., Emmons, R. A., Larsen, R. J. and Griffin, S. (1985) „The Satisfaction With Life Scale,, Journal of Personality Assessment, vol. 49 , no. 1, pp. 71-75.

Diener, E. and Diener, C. (1996) „Most people are happy „, Psychological Science, vol. 7, no. 3, pp.181-185.

Diener, E. and Suh, E. (1997) „Measuring quality of life: Economic, social, and subjective indicators", Social Indicators Research, vol. 40, no. 1, pp. 189-216.
Džuka, J. (2012) „Subjektívne hodnotenie kvality života: definícia, meranie a východiska d’alšieho výskumu®, Československá Psychologie, vol. 56, no. 2, pp. 148-156.

Frisch, M. B., Clark, M. P., Rouse, S. V., Rudd, M. D., Paweleck, J. K., Greenstone, A. and Kopplin, D. A. (2005) „Predictive and treatment validity of life satisfaction and the Quality of Life Inventory", Assessment, vol. 12, no. 1, pp. 66-78.

Griffin, M. A. and Clarke, S. (2011) „Stress and well-being at work,, In: S. Zedeck, APA Handbook of Industrial and Organizational Psychology. Volume 3 (pp. 359-397), Washington: APA.

Hodačová, L. et al. (2011) „Sociální vztahy jako důležitý faktor kvality života dětí", Československá psychologie, vol. 54, no. 1, pp. 1-11.

Janke, W. and Erdmann, G. (2003) Strategie zvládání stresu SVF 78, Praha: Testcentrum.

Kausar, R. (2010) „Perceived Stress, Academic Workloads and Use of Coping Strategies by University Students", Journal of Behavioural Sciences, vol. 20, no. 1, pp. 31-45.

Kebza, V. (2005) Psychosociální determinanty zdraví, Praha: Academia.

Kebza, V. and Šolcová, I. (2010) „Syndrom vyhoření, vybrané psychologické proměnné a rizikové factory kardiovaskulárních onemocnění,,, Československá psychologie, vol. 54, no. 1, pp. 1-16.

Křivohlavý, J., Schwarzer, R. and Jerusalem, M. (1993) Czech Adaptation of the General Self-Efficacy Scale,[online], available at: http://userpage.fu-berlin.de/ health/czec.htm, [cit. 7.3. 2013].

Lazarus, R. S. and Folkman, S. (1984) Stress, appraisal, and coping, New York: Springer. 
Lazarus, R. J. (1999) Stress and Emotion, New York: Springer Publishing Company.

Lukavský, J., Šolcová, I. and Preiss, M. (2011) „Proaktivní zvládání u osob staršího věku: vztah k vybraným kognitivním proměnným๑, Československá psychologie, vol. 55, no. 3, pp. 193203.

Lukeš, M. and Nový, I. et al.(2005) Psychologie podnikání, Praha: Management Press.

Luszczynska, A., Gutierrez-Dona B. and Schwarzer, R. (2005) "General self-efficacy in various domains of human functioning: Evidence from five countries,,, International Journal of Psychology, vol. 40, no. 2, pp. 80-89.

Luszczynska, A., Scholz, U. and Schwarzer, R. (2005) „The General Self-Efficacy Scale: Multicultural Validation Studies,,, The Journal of Psychology: Interdisciplinary and Applied, vol. 139, no. 5, pp. 439-457.

Natovová, L. and Chýlová, H. (2012) "Coping Strategies Adopted by University Students - Part II: Role Conflict and Age", Journal on Efficiency and Responsibility in Education and Science, vol. 5, no. 4, pp. 226-238, ISSN 1803-1617, [on-line], Available: www.eriesjournal.com/_papers/article_195.pdf [2012-12-30]. doi: 10.7160/eriesj.2012.050405.

Neal, A., and Yeo, G. (2003) „Does self-efficacy help or ham performance? An examination of the direction of the relationship between self-efficacy and performance at the within person level of analysis@, Australian Journal of Psychology, vol. 55, no. 1, pp. 138.

Nickerson, C., Diener, E. and Schwarz, N. (2011) ,Positive Affect and College Success,,, Journal of Happiness Studies, vol. 12, no. 4, pp. 717-746.
Norušis, M. J. (2011) IBM SPSS Statistics 19 Advanced Statistical Procedures, New York: Pearson.

Paulík, K. (2010) Psychologie lidské odolnosti, Praha: Grada.

Pavot, W. and Diener, E. (1993) „Review of the Satisfaction With Life Scale@, Psychological Assessment, vol. 5, no. 2, pp. 164-172.

Pavot, W. and Diener, E. (2008) „The Satisfaction With Life Scale and the emerging construct of life satisfaction", The Journal of Positive Psychology, vol. 3, no. 2, pp. 137-152

Scholz, U., Gutierrez-Dona, B., Sud, S. and Schwarzer, R. (2002) „Is General Self-Efficacy a Universal Construct? Psychometric Findings from 25 Countries,,, European Journal of Psychological Assessment, vol. 18, no. 3, pp. 242-251.

Schwarzer, R. and Jerusalem, M. (1995) "Generalized SelfEfficacy scale,,. In J. Weinman, S. Wright, \& M. Johnston, Measures in health psychology: A user's portfolio. Causal and control beliefs (pp. 35-37). Windsor, UK: NFER-NELSON.

Schwarzer, R. (1992) Self-efficacy: Thought control of action, Washington, DC: Hemisphere.

Schwarzer, R., Bäßler, J., Kwiatek, P., Schröder, K. and Zhang, J. (1997) „The assessment of optimistic self-beliefs: Comparison of the German, Spanish, and Chinese versions of the General Selfefficacy Scale,,, Applied Psychology: An International Review, vol. 46, no. 1, pp. 69-88.

Schwarzer, R. and Luszczynska, A. (2008) Self-efficacy, [online], Available: http://dccps.cancer.gov/brp/constructs/self-efficacy/ index.html, [19.3. 2013].

Seligman, M. (2011) Flourish, London: Nicholas Brealey Publishing.

Slezáčková, A. (2012) Průvodce pozitivní psychologií, Praha: Grada. 
Tanaka, M. et al. (2009) „Stress and Coping Styles are Associated with Severe Fatigue in Medical Students", Behavioural Medicine, vol. 35, no. 3, pp. 87-92.

Yeo, G. and Neal, A. (2013) „Revisiting the Functional Properties of Self-Efficacy", The Journal of Management, May 21, ISSN 1557-

1211, [on-line], Available: http://jom.sagepub.com/content/ early/2013/05/20/0149206313490027.full [2013-07-11]. doi: 10.1177/0149206313490027, 